\title{
Evaluation of the bacteriological and physicochemical risk of hospital effluents: case of the Mohamed V hospital in Meknes
}

\author{
Jawad BOUZID ${ }^{*}$, Samira JAOUHAR ${ }^{2}$, Abdelhamid ZAID ${ }^{3}$, Loubna BOUHLOU ${ }^{4}$, and Abdelkader CHAHLAOUI ${ }^{3}$ \\ 1 Hassan First University, Higher Institute of Health Sciences, Health Sciences and Technologies laboratory. Casablanca Road \\ $\mathrm{km} \mathrm{3,} 5$ BP 555 Settat - Morocco. \\ 2 Laboratory of Microbial Biotechnology\& Bioactive Molecules, Faculty of Science and Technology, Sidi Mohammed Ben \\ University Abdeallah Fez. B P 2202, Fes, Morocco \\ 3. Equipe de Gestion et de Développement des Ressources Naturelles, Laboratoire de Santé et Environnement, Faculté des \\ Sciences, Université Moulay Ismail Meknès, Morocco \\ 4 : Laboratoire de Contrôle des eaux Potables \& de la pollution des eaux usées, RADEEM, Meknès, Morocco
}

\begin{abstract}
Like other countries, Morocco is committed to protecting environment. One of the actions is Law 2800 on waste because it is harmful to environment and to health. However, hospital effluents are getting out of hand. This study looked at those at Mohamed V Hospital, which serves a population of almost 2 million people. The methodology relates to physicochemical and bacteriological analyzes of representative samples of these effluents by monthly samples over a period of one year. These were carried out in front of the four wings of the hospital between 11 a.m. and noon (maximum activity period). The search for bacteria of medical interest was carried out at the medical analysis laboratory of the Mohamed V hospital. The bacterial count as well as the physicochemical analyzes were carried out at the drinking water \& wastewater pollution control laboratory of the Autonomous Distribution Authority of Water and Electricity of Meknes and of the environment and health laboratory of the Faculty of Sciences of Meknes. The results showed that some parameters correlate with others and that these effluents pose a threat to the environment and to health. Indeed, the chemical pollution values are high (NH4 +, NO2-, NO3-) compared to WHO standards. The presence of pathogenic germs is demonstrated such as pseudomonas, acinetobacter, clostridium, staphylococcus and streptococcus. On the other hand, these effluents are biodegradable since the COD / DBOS ratio varies between 1.1 and $2(<2)$.
\end{abstract}

\section{Introduction}

Hospitals offer services of various kinds and complexity [1], from simple to more complex procedures such as invasive procedures (surgical procedures, endoscopy, etc.). Indeed, these services allow the care of patients at the level of different care units of the hospital. These generate waste of different kinds. In addition, technological advances in the medical field and the increasingly increased demand for care, lead to an increase in the quantities of waste produced, increasing the risks to human health and the environment [2]. This medical and pharmaceutical waste (D.M.P) is produced by hospitals structures responsible for preventing or reducing risks for patients, professionals and the ecosystem. D.M.P is divided into two types: liquid waste represented by hospital effluents and solid waste [3].

Waste management is unsatisfactory and does not respect the environment; this result has been confirmed by several studies [4]. However, to improve this management, there is no support for effective and appropriate actions; which thus favors an abundance and an increase in negative consequences on environment and on human health [4]. The problem of pollutants' presence in natural environments, especially in water resources, is an international irritation because of environmental, health, strategic, financial and economic issues. Indeed, the generated waste represents between 0.5 and 12 of gross domestic product, of which about one-third for the Healthcare Risk Waste (HCRW) (table I) [5, 6].

In this observation, it's interesting to carry out a study whose objective is to determine degree of physicalchemical and bacteriological pollution related to hospital effluents.

* Corresponding author: jawad.bouzid@uhp.ac.ma 
Table I: Generation of waste from care activities according to Gross Domestic Product.

\begin{tabular}{|c|c|c|}
\cline { 2 - 3 } \multicolumn{1}{c|}{} & $\begin{array}{c}\text { All waste } \\
\text { generated }\end{array}$ & $\begin{array}{c}\text { Healthcare Risk } \\
\text { Waste }\end{array}$ \\
\hline $\begin{array}{c}\text { High gross domestic } \\
\text { product (GDP) }\end{array}$ & 1,1 to 12 & 0,4 to 5,5 \\
\hline $\begin{array}{c}\text { Average gross } \\
\text { domestic product }\end{array}$ & 0,8 to 6,6 & 0,3 to 0,4 \\
\hline $\begin{array}{c}\text { Low gross domestic } \\
\text { product }\end{array}$ & 0,5 to 3 & -- \\
\hline
\end{tabular}

Source: WHO/Safety of Waste Management of Care Activities [6]

Mohamed V hospital of Meknes, given its history, it was built in 1953 and inaugurated on July 17, 1956, by the late His Majesty Mohamed V [8]. In 1987, it was established as Self-Managed State Service in accordance with the joint ordinance of Health Ministry and Finance Ministry $\mathrm{N}^{\circ} 6-87$ of $11 / 27 / 1986$. Its reputation makes it a reference center for care and consultations with regional or even interregional radiation. It is the largest hospital in Meknes /Tafilalt ancient region. According to "High Commission of Planning", it serves a population of around 2,317,000 [9]. It is a vertical hospital consisting of five floors, a ground floor and three subsoil. Its services are arranged in four wings in the shape of a star around a hall [8]. It is located on a constructed area of $3643 \mathrm{~m} 2$ [8]. It offers diagnostic and care in 22 medical specialties [10] with 16,059 admissions in 2014 [9], for a hospitalization rate of $0.69 \%$. The functional Hospital Bed Capacity was 378 in 2013 [8] and in 2014 [9]. Since January 10, 2007, health ministry organizes annually the competition quality between the various structures of health [11]. Nationally, on all editions for hospitals in its class, Mohammed V hospital in Meknes is the most successful: he got the third prize in 2009 and the first prize two successive times in 2010 and 2011.

\section{Materials and methods}

Various physicochemical parameters must be monitored at regular intervals to check physicochemical pollution of discharges. Five-day biochemical oxygen demand, chemical oxygen demand, total suspended solids, total dissolved solids, $\mathrm{pH}$, temperature, exposure time, total nitrogen and total phosphorus are examples of chemical parameters monitored as part of verification [7].

This study was carried out at Mohamed V hospital of Meknes. The frequency of sampling is monthly over a period of one year (March 2013-February 2014) in accordance with the joint ordinance of Equipment Minister and Minister of National Land Use Planning, Town Planning, Housing and Urban Policy n ${ }^{\circ} 1275-01$ of 10 chaabane 1423 (17 October 2002) defining the surface water quality grid, in particular its article 4 which fixes the minimum number of samples on the basis of which the quality of water is assessed at 12 per year for places which are subject to the influence of pollution sources, at a rate of 1 per month [12]. The sampling time corresponds to the maximum activity period, it is between 11 am and 12 noon; P.Jehannin, in 1999 at the C.H. de Hyères, had set the maximum period of care activities between 10 and 11 a.m [13]. The wastewater from each wing flows into its own manhole before reaching the main collector. The latter receives, in addition to the effluents from the four manholes, other wastewater and rainwater

Sample to be analyzed must be homogeneous and representative. Since contamination level is higher or lower depending on the place and time of sampling [14, 4]. The representative samples consist of manhole water corresponding to each of the four wing constituting the hospital's own care units and during hours corresponding to the maximum amount of care.

Samples are transported to laboratory in an enclosure maintained at an equal temperature close to $5^{\circ} \mathrm{C}( \pm 3)[15$, 16]. The water for bacteriological analysis was sampled aseptically in a sterile $500 \mathrm{cc}$ bottle.

Thus the points retained are:

- Point 1 (or station 1): Manhole collecting effluents from wing containing the laboratory, the medical imaging unit, the central operating room, the B1 Surgery departments. Cardiac ultrasound unit and the penitentiary service.

- Point 2 (or station 2): Manhole collecting effluents from wing containing the trauma, infantile surgery, neurology, cardiology and nest departments.

- Point 3 (or station 3): Manhole collecting effluents from wing containing the interim intensive care unit, neurosurgery, surgery A, pediatrics, endocrinology and gastrology departments.

- Point 4 (or station 4): Manhole collecting effluents from wing containing pharmacy services, intensive care unit, surgery B2, burns, pneumology, Medicine C1 and Infectiology.

The location of points (figure 1) is made on a sketch drawn up from a Google-Map that we have translated into a sketch that has been validated by the hospital administration. Samples are taken in subsoil 3 for points 1, 2 and 3, while those in point 4 are taken in subsoil 2.

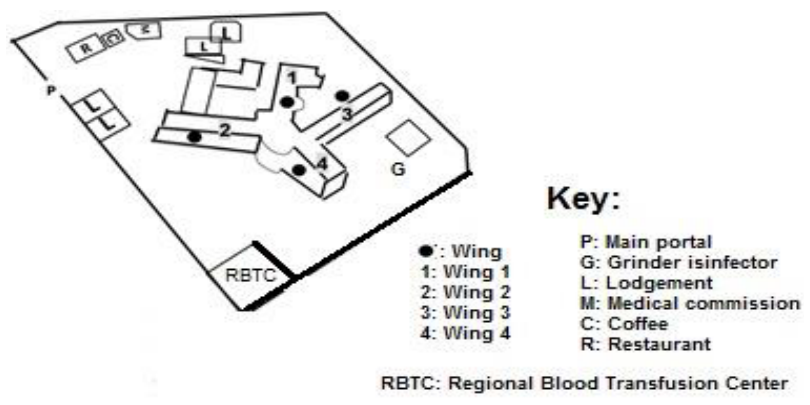

Figure 1: Layout of stations and wings at Mohamed V Hospital

A two liter plastic bottles are prepared to collect the samples. The samples are transported to the laboratory in two enclosures maintained at a temperature of almost 5 ${ }^{\circ} \mathrm{C}$, one of which is transported to medical analysis laboratory at Mohamed V hospital; the other is sent to drinking water and wastewater pollution control laboratory of the Autonomous Water and Electricity Distribution Authority of Meknes (AWEDAM). 
To ensure sample integrity, all analytical procedures are performed or started on the same day of collection or within 24 hours [17]. The arrangement of the four wings is shown in Figure 1.

Bacteriological analysis is divided into two parts: first, the search for and enumeration of bacteria indicative of faecal pollution, carried out at AWEDAM laboratory according to the Rodier 2009 protocol; then looking for bacteria of medical interest (pathogens), carried out in the medical analysis laboratory at Mohamed V Hospital using conventional methods.

Physico-chemical parameters sought are temperature, $\mathrm{pH}$, conductivity, turbidity, SM, NH4 +, NO2-, NO3-, Kjeldehl nitrogen, PO4-, dissolved oxygen, COD and BOD5. They are analyzed according to the protocols recommended by Rodier et al. (2009). Some parameters were measured in situ (temperature, $\mathrm{pH}$ and dissolved oxygen), others in laboratory (Conductivity, turbidity, suspended matter, BOD5, COD, NTK, NO4-, NO2-, NH4 ,+ PO4).

Faecal microbiological contamination of water is a problem that has a major impact on water quality around the world. Pollution indicator bacteria include coliforms (total and fecal), Clostridium Sulfito-Reducers, faecal streptococci $[18,19]$. Bacteria of medical interest sought are those that could be found in hospital wastewater. They are thought to be present in stool or in urine (Salmonella, Shigella, Coliforms, Vibrios, Streptococci, Enterobacteriaceae, etc.) [14] or bacteria responsible for infections associated with care (Staphylococci, Streptococci, Pseudomonas, etc.) [14,20].

\section{Résultats:}

\subsection{Physicochemical parameters}

Descriptive statistics of physicochemical parameters are shown in Table II.

Temperature: average temperature recorded is $23,265^{\circ} \mathrm{C}$ and oscillates between $18^{\circ} \mathrm{C}$ and $34^{\circ} \mathrm{C}$. The maximum temperature, $34^{\circ} \mathrm{C}$, was recorded at station 4 during the month of June. Thus, these effluents are classified of medium quality according to the Moroccan standard (class 2). High temperatures are recorded during the summer season (June, July and August) and low temperatures are recorded during the winter season.

Hydrogen potential $(p H)$ : Results show that hospital effluents comply with biological $\mathrm{pH}$ range which is between 6.5 and 8.5 [21] because their $\mathrm{pH}$ oscillates between 6 and 8.83 with an average of 7.48 . We note that the only months that recorded an alkaline $\mathrm{pH}$ are April and September with 8.09 and 8 respectively and that in general effluents from Mohamed V hospital are basic.

Table II: Descriptive statistics of physicochemical analyzes

\begin{tabular}{|c|c|c|c|c|c|}
\hline Variable & Min & Max & Moy & $\begin{array}{c}\text { Standard } \\
\text { deviation }\end{array}$ \\
\hline $\mathbf{t}^{\circ}\left({ }^{\circ} \mathbf{C}\right)$ & 18,3 & 34 & 23,265 & 4,94 \\
\hline pH & 6,5 & 8,83 & 7,504 & 0,47 \\
\hline Dissolved O2 & 0,16 & 8,1 & 2,339 & 2,16 \\
\hline $\begin{array}{c}\text { Conductivity } \\
\text { uS/cm }\end{array}$ & 62 & 14586 & 2250,51 & 2793,05 \\
\hline Turbidity & 2,3 & 718 & 136,77 & 186,59 \\
\hline Suspended & 26,7 & 780 & 229,16 & 190,56 \\
\hline solids & 20 & 2890 & 580,16 & 706,57 \\
\hline BOD5 (mg/l) & COD (mg/l) & 33 & 5080 & 1043,56 & 1079,07 \\
\hline NH4+ & 2 & 479 & 57,87 & 102,91 \\
\hline NTK & 9,6 & 532,4 & 63,36 & 93,18 \\
\hline NO2- & 0,01 & 19,7 & 3,26 & 4,76 \\
\hline PO4- & 0,33 & 128,74 & 21,65 & 27,32 \\
\hline NO3- & 0,01 & 92,92 & 37,24 & 33,34 \\
\hline
\end{tabular}

Dissolved oxygen: Dissolved oxygen testifies to viability of bacterial species. In the present study, it varies from $0.16 \mathrm{mg} / 1$ to 12.7 with an average of $2,339 \mathrm{mg} / 1$. The maximum dissolved oxygen value was recorded at station S2 in August, while low values were recorded at station S1 in March and November.

Conductivity: Study of evolution of parameters indicative of salinity showed that measurement of the average electrical conductivity reached a value of 2250,51 $\mu \mathrm{s} / \mathrm{cm}$ with a very large variation ranging from 62 to $14586 \mu \mathrm{s} / \mathrm{cm}$.

Turbidity (NTU): Turbidity recorded varies between 2.3 and 718 NTU (Nephelometric Turbidity Unit) with an average of almost 136,77 NTU.

Suspended matter (SM): SM vary between 26,7 and $780 \mathrm{mg} / 1$ with an average of 229,16 mg / 1 .

Biological oxygen demand (BOD5): Average BOD5 is $580,16 \mathrm{mg} / 1$ with a large variation, ranging from 20 to $2890 \mathrm{mg} / 1$. High values are noted at station S4 in April and May while low values are recorded at station S1 in winter and summer.

Chemical oxygen demand (COD): At Mohamed V hospital in Meknes, COD varies dramatically from 33 to $5080 \mathrm{mg} / 1$ with an average value of 1043,56 mg / 1 . COD values are important at stations S3 and S4 during the spring season.

Nitrogen compounds: Table III shows the descriptive data relating to nitrogen compounds in effluents of Mohamed V Hospital.

Table III: Nitrogenous compounds contained in effluents of Mohamed V hospital in Meknes 


\begin{tabular}{|c|c|c|c|c|}
\cline { 2 - 5 } \multicolumn{1}{c|}{} & NH4+ & NTK & NO2- & NO3- \\
\hline Average & 57,87 & 63,36 & 3,26 & 37,24 \\
\hline Minimal & 2,00 & 9,6 & 0,01 & 0,01 \\
\hline Maximal & 479,00 & 532,40 & 19,7 & 92,92 \\
\hline WHO standard & $<0,5$ & $<4$ & 1 & $<1$ \\
\hline
\end{tabular}

\subsection{Bacteriological parameters}

Clostridium is present with an average concentration of $164 \mathrm{CFU} / 100 \mathrm{ml}$ (from 7 to $1407 \mathrm{CFU} / 100 \mathrm{ml}$ ). Total coliforms are present with an average of 4.5.10 ${ }^{6} \mathrm{CFU} /$ $100 \mathrm{ml}$ with a very significant variation ranging from $8.10^{2}$ $\mathrm{CFU} / 100 \mathrm{ml}$ to $12.10^{7} \mathrm{CFU} / 100 \mathrm{ml}$. Thermo-tolerant coliforms (feces) are identified at an average concentration of $10^{5} \mathrm{CFU} / 100 \mathrm{ml}$. The enumeration of streptococci led to an average value of $1.35 .10^{8} \mathrm{CFU} / 100$ $\mathrm{ml}$. Bacteriological analysis identified and isolated Pseudomonas putida, Acinetobacter baumanii, Staphylococcus aureus, Streptococcus sp., Clostridium perfengens. Enterobacter aerogenes, Proteus sp, Serratia marcescens and Escherichia coli.

\section{Discussion}

\section{Temperature:}

Temperature plays a very important role in solubility of salts and especially gases, and $\mathrm{pH}$ determination [22]. It also acts as a physiological factor on growth metabolism of microorganisms living in water. The average temperature recorded is $23,265^{\circ} \mathrm{C}$, compared to $18.9^{\circ} \mathrm{C}$ at the same hospital in 2013 [23]. This increase could be explained, first by the fact that effluent pipe passes near boiler and kitchen just before being emptied into view and second by temperature influence of discharges in exit from laundry, from that of oils and fats from kitchen. This result is in accordance with the international standard established by WHO (1986) which sets the maximum temperature at $30^{\circ} \mathrm{C}$. Thus, these effluents are classified of medium quality according to the Moroccan standard (class 2). These values agree with those recorded at Sidi Kacem hospital center with a temperature varying from 17 to $22^{\circ} \mathrm{C}$ with an average of $19.8^{\circ} \mathrm{C}$ [24] and those at Elghassani hospital in Fez which is $17.11^{\circ} \mathrm{C}[25]$.

\section{Hydrogen potential $(p H)$ :}

Hydrogen potential varies depending on nature of the basic or acidic effluents. It is an indicator of water pollution. The biological $\mathrm{pH}$ range is $6.5-8.5$, lowering $\mathrm{pH}$ can increase toxicity [21]. Results show that effluents from Mohamed V Hospital comply with biological $\mathrm{pH}$ range which is between 6.5 and 8.5 [21] because their average $\mathrm{pH}$ is 7.48 . This $\mathrm{pH}$ increased from 2013 when it was 6.9 [23]. We note that in general the effluents from Mohamed V Hospital are basic. According to Moroccan standards, these effluents switch between good and bad quality. In France, the interval is 5.5 to 8.5 [26]. The $\mathrm{pH}$ of wastewater from Sidi Kacem hospitals in 2012 was around 7.27 [24]. In Lyon, Boillot noted in 2008 a pH ranging from 5 to 8.8 [27].

\section{Dissolved oxygen:}

Dissolved oxygen testifies to the viability of bacterial species. In the present study, its average content of 2,339 $\mathrm{mg} / \mathrm{l}$ increased by $2.03 \mathrm{mg} / \mathrm{l}$ since 2013 [23]. "The classes of aptitude for biology" of the 2nd version of the Evaluation Grids of the System for evaluating the quality of water in rivers classifies these effluents in the red zone and therefore of poor quality [28]. This wastewater is of poor to very poor quality according to Moroccan standards [29].

\section{Conductivity:}

Study of the evolution of parameters indicative of salinity has shown that measurement of average electrical conductivity has more than doubled since 2013 (969.67 $\mu \mathrm{s} / \mathrm{cm}[23])$ to reach a value of $2250,51 \mu \mathrm{s} / \mathrm{cm}$ with a very large variation ranging from 62 to $14586 \mu \mathrm{s} / \mathrm{cm}$. The Moroccan standard classifies these effluents between class 3 and 5 that is to say from average to very poor quality. At Sidi Kacem Provincial Hospital, average conductivity is $3140 \mu \mathrm{s} / \mathrm{cm}$ [24] while Boillot, in Lyon, recorded, for 17 hospitals, an interval ranging from 11.2 to $313 \mu \mathrm{s} / \mathrm{cm}$ [27].

\section{Turbidity (NTU):}

Replication of microorganisms is noted by production of turbidity [30]. That, raised is on average 136,77 NTU. We can then say that these effluents are very cloudy since discharge standard is 5 to $30 \mathrm{NTU}$. This result is not in line with that of provincial hospital of Sidi Kacem in 2012 where turbidity is $14.76 \mathrm{NTU}$ [24] and that of two large hospitals in region of Rabat Salé Zemmour Zaer in 2014 where it varies between 18 and 194 NTU [31].

\section{Suspended matter (SS):}

The average SS content $(229,16 \mathrm{mg} / \mathrm{l})$ has fallen by almost half compared to 2013 [23] but remains largely high compared to the WHO standard which is less than 20 $\mathrm{mg} / \mathrm{l}$. The suspended solids concentration must not exceed $100 \mathrm{mg} / 1$ in the case of discharge into a collective sanitation network without a wastewater treatment plant [32] such as in the case of Mohamed V hospital. the latter comply with the Moroccan standard being set at a value between 200 and 1000 [29], but remain above wastewater discharge standards set at $50 \mathrm{mg} / 1$ [24]. These results are in line with those of Sidi Kacem hospital where SS content was $233.33 \mathrm{mg} / \mathrm{l}$ in 2012 [24], with those in Lyon in 2008 where they were 46 to $298 \mathrm{mg} / 1$ [27] and with those of CHRU in Limoges where average suspended solids was $77 \mathrm{mg} / 1$ in 2002 [14]. In United States of America, hospital wastewater is mainly domestic and characterized by a solids content of between 60 to 200 $\mathrm{mg} / 1$ [27].

\section{Biological oxygen demand (BOD5):}


The average BOD5 of effluents from Mohamed V hospital decreased by approximately $25 \%$ from 2013 to now with $737.5 \mathrm{mg} / 1$ [23] and 580,16 mg/1 respectively. Most often, it is far from within the WHO discharge standards set at less than $30 \mathrm{mg} / 1$ [21]. It must not exceed $100 \mathrm{mg} / \mathrm{l}$ (32) or must be between 50 and $400 \mathrm{mg} / 1$ [33]. The Moroccan standard classifies these effluents as being very bad since their BOD5 content exceeds $25 \mathrm{mg} / 1$ [29]. These results are not similar to those of provincial hospital of Sidi Kacem in which wastewater has a BOD5 content of $44.66 \mathrm{mg} / 1$ [24]. They are also not consistent with Darsy et al. at Limoges University Hospital in 2002 with a BOD5 measured at $177 \mathrm{mg} / \mathrm{l}$ on average and which reached $1095 \mathrm{mg} / \mathrm{l}$ as a maximum value [14]. United States-Environmental Protection Agency (US EPA) in 1989, points out that "wastewater from hospitals is essentially domestic and can be characterized by measuring global parameters within following limits: BOD5: 50 to $400 \mathrm{mg} / 1$ [27].

\section{Chemical oxygen demand (COD):}

At Mohamed V hospital, the COD, with an average value of $1043,56 \mathrm{mg} / 1$, decreased from $1420 \mathrm{mg} / 1$ in 2013 [23]. The effluents are thus classified as being of very poor quality according to Moroccan standards (COD> $80 \mathrm{mg} / \mathrm{l})$. This content is well above WHO standard which is set at less than $90 \mathrm{mg} / 1$. At Elghassani hospital in Fez in 2009 , it is $115.2 \mathrm{mg} / 1$ to $617.5 \mathrm{mg} / 1$ [25]. At Limoges CHRU, it is on average equal to $539 \mathrm{mg} / 1$ [14]. In United States of America, United States-Environmental Protection Agency (US EPA) in 1989, indicates that the COD limits of hospital effluents are between 150 to 800 $\mathrm{mg} / \mathrm{l}$, classifying them as being mainly domestic [27].

\section{Nitrogen compounds:}

Nitrogen exists mainly in ionic form (ammonium $\mathrm{NH}_{4}{ }^{+}$, nitrite $\mathrm{NO}_{2}$ and nitrate $\mathrm{NO}_{3}{ }^{-}$) as well as in gaseous form $\left(\mathrm{N}_{2}\right)$. Hospital wastewater contains organic nitrogen and ammoniacal nitrogen. The first is an element constituting living cells. The second $\left(\mathrm{NH}_{4}^{+}\right)$comes from decomposition of organic nitrogen by bacteria and direct discharges (urine, feces). Ammonia and nitrogen dioxide pose problems for public health. They induce bacterial proliferation in water. The main source of concern is NO3 nitrates. These ions are transformed in a weak acidic medium into nitrite ions which are toxic to human organism. Levels of ammonium, Kjeldahl nitrogen, nitrites and nitrates are all in excess of discharge standards set by WHO [28]. By comparing our results with Moroccan standards [29], we can advance that in terms of ammonium and Kjeldahl nitrogen, effluents from Mohamed V hospital are classified as very bad (NH4 +> $8 \mathrm{mg} / 1$ and NTK $>3 \mathrm{mg} / \mathrm{l}$ ), while in terms of nitrates, they are classified as of medium quality (NO3 - between 25 and $50 \mathrm{mg} / \mathrm{l})$.

\section{Orthophosphates:}

The average phosphate levels $(21,65 \mathrm{mg} / \mathrm{l})$ increased since they were at a value of $10.65 \mathrm{mg} / \mathrm{l}$ in 2013 [23] and. They exceed WHO phosphate standard, which is set at a content of less than $2 \mathrm{mg} / \mathrm{l}$ [28]. While for Boillot, in Lyon, they are between $6.15 \mathrm{mg} / \mathrm{l}$ and $17.3 \mathrm{mg} / 1$ [27].

\section{Results by parameter (analysis):}

Descriptive statistics of physicochemical parameters are presented in Table II. The correlation matrix (Pearson (n)) tells us that there are four positive correlations. These are:

- The COD correlates positively with BOD5 (0.927) and SM (0.631)

- $\mathrm{NH}_{4}{ }^{+}$correlates positively with BOD5 (0.567), COD (0.647)

- Kjeldahl nitrogen correlates positively with $\mathrm{NH}_{4}{ }^{+}$ (0.742), SM (0.663), BOD5 (0.718), COD (0.784)

- $\mathrm{NO}_{2}$ positively correlates with $\mathrm{NH}_{4}^{+}(0.509), \mathrm{SM}$ (0.511), BOD5 (0.893), DCO (0.799), NTK (0.715)

Principal Component Analysis:

$\mathrm{F} 1$ and $\mathrm{F} 2$ axes have $53.88 \%(40,3$ et 13,6$)$ of information. Analysis of results shows that most of information is explained by the first two factor axes.

The formation of factorial axes $\mathrm{F} 1$ and $\mathrm{F} 2$ is characterized by the fact that no parameter contributes more than $20 \%$ (table IV). Based on the principle that only variables whose contribution is greater than the average contribution are retained for interpretation (Table IV), we can state that: BOD5, COD, nitrites, ammonium and Kjeldahl nitrogen are well represented on F1 axis; while temperature, conductivity, SM, NTK and orthophosphates are well represented on F2 axis. Nitrates are well represented on both axes.

Figure 2 shows that there are two well-distinguished correlation groups: the first consists of biological oxygen demand (BOD5), chemical oxygen demand (COD), nitrites $\left(\mathrm{NO}_{2}^{-}\right)$, ammonium $\left(\mathrm{NH}_{4}^{+}\right)$, suspended solids, turbidity, nitrate ions $\left(\mathrm{NO}_{3}{ }^{-}\right)$, conductivity and hydrogen potential $(\mathrm{pH})$ and Kjeldahl nitrogen (NTK). While the second group is made up of orthophosphates $\left(\mathrm{PO}_{4}\right)$ and dissolved oxygen.

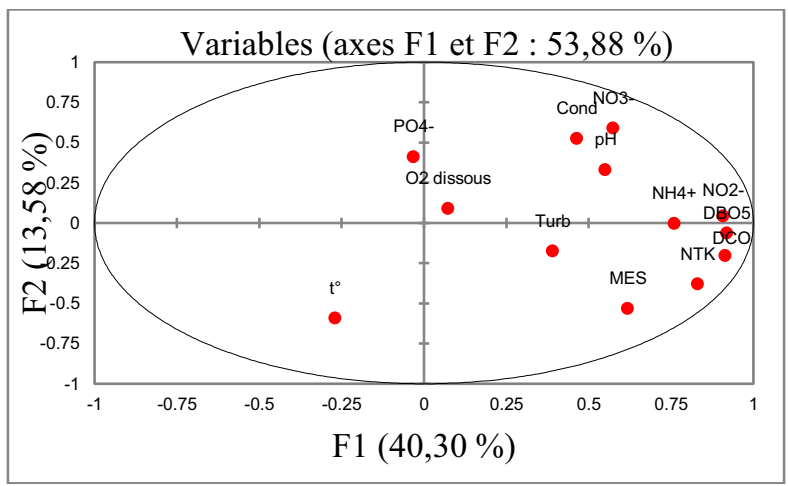

Figure 2 : Graphic representation of PCA

Organic and mineral pollution gradient starts from station S3, passes first through station S2 then station S4 and finally station S1 (figure 3). Orthophosphates are more important in S2 and S4 stations (figure 2 and figure 3) 


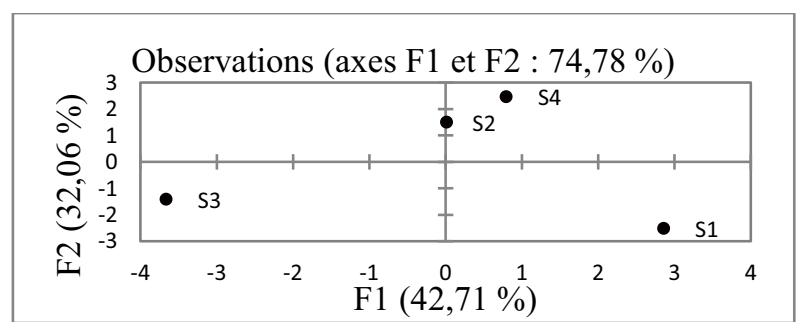

Figure 3: Principal Component Analysis of stations

Station S2 correlates positively with station S4 (Figure 3). Biological oxygen demand (BOD5), chemical oxygen demand (COD), nitrites $\mathrm{NO} 2$, ammonium $\mathrm{NH}_{4}{ }^{+}$and Kjeldahl nitrogen NTK are well represented on F1 axis (table IV and figure 2). On the other hand, temperature, conductivity, suspended matter MES, Kjeldahl NTK nitrogen, orthophosphate $\mathrm{PO} 4+$ and nitrates NO3- are well represented on F2 axis (table IV and figure 2).

Table IV: Contributions of variables (\%):

\begin{tabular}{|l|l|l|}
\hline & \multicolumn{1}{c}{ F1 } & \multicolumn{1}{c}{ F2 } \\
\hline $\mathrm{t}^{\circ}\left({ }^{\circ} \mathrm{C}\right)$ & 1,383 & 19,755 \\
\hline $\mathrm{pH}$ & 5,790 & 6,212 \\
\hline Dissolved O2 & 0,103 & 0,462 \\
\hline Conductivity & 4,105 & 15,670 \\
\hline Turbidity & 2,917 & 1,724 \\
\hline Suspended matter & 7,315 & 16,023 \\
\hline BOD5 & 16,134 & 0,224 \\
\hline COD & 15,963 & 2,345 \\
\hline NH4+ & 11,026 & 0,000 \\
\hline NTK & 13,198 & 8,145 \\
\hline NO2- & 15,743 & 0,111 \\
\hline PO4- & 0,019 & 9,616 \\
\hline NO3- & 6,303 & 19,714 \\
\hline Average contributions & 7,692 & 7,692 \\
\hline
\end{tabular}

Physico-chemical analyzes of effluents from Mohamed V hospital concluded that these present both organic and mineral pollution with reference to national and WHO standards. Results showed that these effluents pose a threat to environment and health. Indeed, chemical pollution values are high $\left(\mathrm{NH}_{4}{ }^{+}: \mathrm{avg}=59.6 \mathrm{mg} / \mathrm{l}\right.$ against WHO standard of $0.5 \mathrm{mg} / 1 ; \mathrm{NO}_{2}^{-:}: 3.7 \mathrm{mg} / \mathrm{l}$ against WHO standard which is $1 \mathrm{mg} / 1 ; \mathrm{NO}_{3}{ }^{-:}: 34.54 \mathrm{mg} / 1$ against WHO standard which is $1 \mathrm{mg} / \mathrm{l}$; Kjeldahl nitrogen (NTK): 60.21; orthophosphates PO4: $18.56 \mathrm{mg} / \mathrm{l})$. On other hand, Mohamed V hospital effluents are biodegradable since average COD / DBOS ratio is $1.76(<2)$.

\section{Evolution of physico-chemical parameters over the years:}

Effluents of Mohamed V Hospital in Meknes change over time. To follow this evolution, we compared our results for certain parameters with those of 2013 (23) for the same hospital.

- Temperature: over years, effluents of Mohamed V hospital have gained almost $4{ }^{\circ} \mathrm{C}$ between 2013 and 2016 .

- The $\mathrm{pH}$ : it has evolved with +0.4

- The conductivity rose from 969 to 2611 , ie an increase of $+270 \%$.

- The ratio between dissolved oxygen content of our study and that of 2013 is equal to 3.74 .

- SM fell by almost half
- BOD5 and COD lost $25 \%$ and $32 \%$ respectively from 2013 currently.

- Nitrite concentration fell by $80 \%$, going from $18.09 \mathrm{mg} / 1$ in 2013 to $3.7 \mathrm{mg} / \mathrm{l}$ now. On other hand, nitrate content increased more than ten times, going to $34,54 \mathrm{mg} / 1$ currently after having been at $3.19 \mathrm{mg} / \mathrm{l}$.

- Orthophosphates increased by a coefficient of 1.74 .

\section{Conclusion}

Results showed that some parameters correlate with others and that these effluents pose a threat to environment and to health. Indeed, chemical pollution values are high ( $\left.\mathrm{NH} 4+, \mathrm{NO}_{2}-, \mathrm{NO}_{3}-\right)$ compared to WHO standards. Presence of pathogenic germs is demonstrated such as pseudomonas, acinetobacter, clostridium, staphylococcus and streptococcus. On other hand, these effluents are biodegradable since the COD / DBOS ratio varies between 1.1 and $2(<2)$.

\section{Références}

1. J.R. Loubat ,. " Chapitre 8. Identifier et présenter ses prestations de service ». [auteur du livre] Jean-René Loubat. Elaborer un projet d'établissement ou de service en action sociale et médico-sociale. Paris : Paris, Dunod, 2012, pp. 203-234.

2. A. Abdelsadok,. Etude d'accompagnement pour de la gestion des déchets médicaux au Maroc, capitalisation de l'expérience française. Mémoire de Mastère Spécialisé. s.l. : Ecole Nationale du Génie de l'Eau et de l'Environnement de Strasbourg, 2010. pp. 15-20.

3. JM. Di guardia, Les déchets d'activités de soins. [En ligne] 2010. [Citation : 15 Juillet 2013.] ars-npdcsanteenvironnement@ars.sante.fr.

4. C. Dremont, R. Hadjali. La gestion des effluents liquides en milieu hospitalier. Techniques biomédicales hospitalières. Université de Technologie de Compiègne, 1997. projet de DESS "". http://www.utc.fr/ farges/DESS_TBH/96-

97/Projets/EL/EL.htm.

مخلفات الرعاية الصحية صحيفة وقائع. الإعلام, مركز وسائل. 253, . 5.

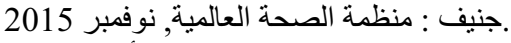

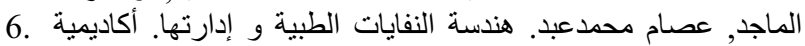
2006, Vol. 1.

7. OMS. Directives OMS pour l'utilisation sans risque des eaux usées, des excréta et des eaux ménagères. 2012.

8. J. Bouzid, A. Chahlaoui, A. Bouhlal, K. Ouarrak. Caractérisation du risque bactériologique des déchets médicaux et pharmaceutiques solides de l'hôpital Mohamed V de Meknès. International Journal of Innovation and Scientific Research. ISSR Journals, Vol. 20, 2, pp. 259-267. Maroc (02 Fevrier 2015)

9. Direction de la Planification et des Ressources Financières. Santé en chiffres 2014 édition 2015. [éd.] Ministère de la santé. 2015, 2015.

10. J. Bouzid, A. Chahlaoui, A. Bouhlal, S. Aababou, M. Aarab, I. Jari. Détermination de la prévalence des infections du site opératoire chez les opérés de l'hôpital Mohamed V de Meknès. IJISR, Vol. 14, 2, pp. 198-207. Maroc (2015)

11. A. Gouiss. Effets du concours qualité sur les comportements des professionnels: de sante cas des 
hôpitaux de la région du Gharb Chrarda Bni Hssen. Rabat : Ecole Nationale de Santé Publique, 2013. p. 24, Mémoire pour l'obtention de mastère en administration sanitaire et santé publique.

12. Ministre de l'Equipement, Le Ministre Chargé de l'Aménagement du Territoire, de l'Urbanisme, de l'Habitat et de l'Environnement. Arrêté conjoint du ministre de l' équipement et du ministre chargé de l' aménagement du territoire, de l' urbanisme, de l' habitat et de l' environnement définissant la grille de qualité des eaux de surface. Bulletin Officiel. Rabat : Secrétariat général du gouvernement, 05 Décembre 2002. Vol. 5062, $\mathrm{n}^{\circ}$ 1275-01, pp. 1523-1526.

13. P. Jehannin. Caractérisation et Gestion des Rejets Liquides Hospitaliers - Etudeparticulière de la situation du C.H. de Hyères (Var). Ecole Nationale de la Santé publique. 1999. Mémoire de fin d'études.

14. C. Darsy, I. Lescure, V. Payot et G. Rouland. Effluents des établissements hospitaliers : teneur en microorganismes pathogènes, risques sanitaires, procédures particulières, d'épuration et de gestion des boues. [éd.] Service National d'Information et de Documentation sur l'Eau. LIMOGES : Office International de l'Eau. (février 2002)

15. Service Industriels du SIARP. Guide méthodes de mesure, prélèvement et analyses des eaux usées. s.l., Région de Cergy-Pontoise et du Vexin : Syndicat Intercommunautaire pour l'Assainissement. (2011)

16. Normalisation, Association Française de. FD T 90523-2: «Qualité de l'Eau - Guide de prélèvement pour le suivi de qualité des eaux dans l'environnement Prélèvement d'eau résiduaire. Norme Française. s.l. : Boutique AFNOR Editions. FD T 90-523-2. (Octobre 2019)

17. P.Alégoët. Contrôle sanitaire des eaux, Guide de prélèvement. s.l. : Service Santé-Environnement, 2006.

18. A. Aboulkacem, A. Chahlaoui, A. Soulaymani, F. Rhazi-Filali, D. Benali. Etude comparative de la qualité bactériologique des eaux des oueds. Revue de Microbiologie Industrielle Sanitaire et Environnementale, Vol. 1, 1, pp. 10-22. (2007)

19. M. Larif, A. Soulaymani et A. Elmidaoui. Evaluation spatio-temporelle du degré de la pollution industrielle oléicole sur les cours d'eaux de l'oued Boufekrane dans la région de Meknès-Tafilalt $J$. Mater. Environ. Sci., Vol. 4, pp. Pp. 432-41. Maroc (2013)

20. C.T. Tsai, J.S. Lai et S.T. Lin. Quantification of pathogenic micro-organisms in the sludge from treated hospital wastewater. J Appl Microbiol, Vol. 1, 85, pp. 171-6. (1998)

21. J. Rodier, B. Legube, N. Merlet. L'Analyse de l'eau. 9ème édition. Technique et Ingénierie Paris : DUNOD, Vol. 9. p.1511. ISBN.978-2-10-054179-9. (2009)

22. F. Cheikh. Etude de la qualité de l'eau de robinet et de celle de la nappe phréatique dans les différentes Communes d'Arrondissement du département de Guédiawaye, Dakar, Sénégal. Memoire Online. [En ligne]. [Citation : 10 Juillet 2016.] Mémoire pour l'obtention du diplôme de Matrise. http://www.memoireonline.com/08/09/2625/m_Etudede-la-qualite-de-leau-de-robinet-et-de-celle-de-la-nappephreatique-dans-les-di13.html. (2007)
23. N. Ameziane. Déchets hospitaliers entre gestion et impact sur l'environnement et la santé humaine, cas de l'hôpital Mohamed V de Meknès. Faculté des Sciences et Techniques - Fès. Fès : Universite Sidi Mohamed Ben Abdellah, p. 240, thèse de doctorat. (2013)

24. S. Sadek. Caractérisation physico-chimique des eaux usées de l'hôpital provincial de Sidi Kacem (Maroc). [éd.] Mersienne. ScienceLib., Vol. 4, pp. p1-p8. (2012)

25. M. El Tahiri, C. Nejjari, L. Benabbbidate. K.F. Benbrahim. Caractérisation des effluents liquides de l'hôpital Al Ghassani, CHU Hassan II de Fès. Les effluents Liquides des établissements de santé : état des Lieux et perspectives de gestion. Revue hospitalière de France. Maroc (2009)

26. ND. Arrêté du 2 juin 1998 relatif aux prescriptions générales applicables aux installations classées pour la protection de l'environnement, France. 1998.

27. C. Boillot. Caractérisation écotoxicologue d'un effluent hospitalier : Evolution durant une journée normale d'activité. 2008, $\mathrm{N}^{\circ}$ d'ordre ISAL 0021.

28. MEDD \& Agences de l'Eau. Système d'évaluation de la qualité de l'eau des cours d'eau (SEQ-Eau). s.l. : MEDD \& Agences de l'eau, 2003. p. 2. 